Article

\title{
Entrepreneurial Sustainability Engagement of Insiders Initiating Energy System Transition
}

\author{
Niklas Fernqvist ${ }^{1,2, *(D)}$ and Mats Lundqvist ${ }^{2}$ (D) \\ 1 Policy and Innovation, Research Institutes of Sweden (RISE), SE-501 15 Borås, Sweden \\ 2 Department of Technology Management and Economics, Chalmers University of Technology, \\ 41296 Gothenburg, Sweden; mats.lundqvist@chalmers.se \\ * Correspondence: niklas.fernqvist@ri.se
}

check for

updates

Citation: Fernqvist, N.; Lundqvist, M.

Entrepreneurial Sustainability

Engagement of Insiders Initiating

Energy System Transition.

Sustainability 2021, 13, 734. https://

doi.org/10.3390/su13020734

Received: 21 December 2020

Accepted: 12 January 2021

Published: 14 January 2021

Publisher's Note: MDPI stays neutral with regard to jurisdictional clai$\mathrm{ms}$ in published maps and institutional affiliations.

Copyright: $(\odot 2021$ by the authors. Licensee MDPI, Basel, Switzerland. This article is an open access article distributed under the terms and conditions of the Creative Commons Attribution (CC BY) license (https:// creativecommons.org/licenses/by/ $4.0 /)$.

\begin{abstract}
The central point in this article is that energy system transition can be initiated by a team of individuals interacting entrepreneurially beyond their different home-grounds in business, research, or regional development. Such entrepreneurial engagement of insiders with belongings to an established socio-technical system has not been captured in prevalent sustainability transitions or entrepreneurship perspectives. Insiders have mostly been expected to act within (and not outside) of their role expectations. This study investigates who individuals initiating energy transition are, what motives they have, and how they accomplish institutional change. The purpose is to qualify a perspective that can help us better appreciate how transitions, such as in energy systems, can be initiated. The new perspective recognizes the importance of insiders, their personal sustainability beliefs, their choice to teamwork entrepreneurially, and their narratives about the initiative affecting institutional change. It explains how transition in a heavily regulated Swedish energy system can occur. Implications are drawn for research, policy and entrepreneurial teamwork.
\end{abstract}

Keywords: insiders; entrepreneurial engagement and teamwork; sustainability transitions; narratives

\section{Introduction}

Increased decentralization in the energy system is a way of localizing energy production and balance local energy needs. Decentralization thus enables increased renewable energy production and has potentially a positive effect on the energy system at large. However, decentralizations in the energy system challenge core business models of established energy industry, to sell and deliver energy. As such, decentralization brings uncertain futures to the energy sector as increased decentralization implies consumers becoming 'prosumers', i.e., consumers who also produce energy, or consumers optimizing between different energy sources, such as district heating and electricity. As established energy systems are heavily regulated and mostly in the hands of an incumbent energy industry, there is little ability for new entrants to gain a position and make change. Local grassroot experiments will mostly stay at the grassroot level and entrepreneurial ventures are hindered by regulations.

The purpose of this study is to qualify an insider sustainability engagement perspective that can help us better appreciate how transition, such as in energy systems, can be accomplished. The study takes stock of two Swedish energy systems initiatives, involving insiders, i.e., individuals employed by established firms and organizations. These initiatives are two of few examples in Sweden, having transitional effects upon an otherwise heavily regulated and difficult to change energy system. The narratives of these individuals are voiced, displaying not only who they are and what personal beliefs that steer their entrepreneurial bottom-up engagement, but also how institutional transition effects are achieved through their inclusive entrepreneurial teamwork. 


\section{Theory}

When an employee of an established organization takes actions beyond what is expected in his or her organizational role, and because he or she thinks it is of importance for sustainability reasons, we call this entrepreneurial insider sustainability engagement. In other words, insider sustainability engagement is when insiders engage in entrepreneurial ways into sustainability initiatives because of personal sustainability beliefs.

In sustainability transitions research, a central aim is to conceptualize and explain how radical changes in socio-technical systems occur in ways that also fulfil societal functions [1]. It is then often recognized that initiatives to try out new solutions are important for creating networks, reducing uncertainty of new technologies and applications, open up for new social spaces and politics for governing towards the future [2-9]. Sustainability initiatives for testing out new solutions are found in and around many socio-technical systems, such as in cities, the transportation and the energy sector $[10,11]$ and are seen as necessary to achieve transitional change e.g., [12-16]. However, the link between initiatives, the individuals engaging into them and institutional transitional effects are not well understood [1,17]. In regulated environments, where expertise and power are associated to incumbent industry, it is difficult to expect change to come top-down or through new entrants. Instead, a perspective where individuals belonging to incumbents choose to engage independently through an entrepreneurial team can be fruitful.

Table 1 displays how established perspectives within sustainability transitions and entrepreneurship relate to three aspects of an entrepreneurial insider sustainability engagement perspective. Three questions are posed to each perspective: (1) are insiders, i.e., individuals employed by incumbent organization's within a sociotechnical regime, appreciated in the perspective? (2) does the perspective comprise individuals who choose to engage in bottom-up entrepreneurial ways? and (3) does the perspective recognize individuals driven by personal sustainability beliefs?

Table 1. Overview of how aspects of bottom-up insider engagement in sustainability initiatives are recognized in established perspectives around sustainability transitions and entrepreneurship.

\begin{tabular}{|c|c|c|c|}
\hline Perspective & $\begin{array}{l}\text { (1) Appreciates Insiders-i.e., } \\
\text { Individuals with Employments } \\
\text { Within the Socio-Technical Regime? }\end{array}$ & $\begin{array}{l}\text { (2) Comprises Individually } \\
\text { Chosen Entrepreneurial Actions? }\end{array}$ & $\begin{array}{l}\text { (3) Recognizes Personalized } \\
\text { Sustainability Beliefs? }\end{array}$ \\
\hline Multi-level perspective & No & Yes, but only in niches & Yes, but only in niches \\
\hline Technological innovation systems & No & $\begin{array}{l}\text { Yes, in entrepreneurial } \\
\text { experimentation }\end{array}$ & No (with some exceptions) \\
\hline Transition management & Yes & $\begin{array}{l}\text { Not individually chosen, but } \\
\text { linked to roles in processes }\end{array}$ & $\begin{array}{l}\text { Not personalized, but } \\
\text { ascribed to roles in process }\end{array}$ \\
\hline Mainstream Entrepreneurship & No & Yes & No \\
\hline $\begin{array}{l}\text { Corporate entrepreneurship/ } \\
\text { Intrapreneurship }\end{array}$ & Yes & Yes & No \\
\hline Social entrepreneurship & No & Yes & Yes \\
\hline $\begin{array}{l}\text { Entrepreneurial insider } \\
\text { sustainability engagement } \\
\quad \text { (introduced here) }\end{array}$ & Yes & Yes & Yes \\
\hline
\end{tabular}

\subsection{Sustainability Transitions Perspectives}

The multi-level perspective is one of the main established perspectives within sustainability transitions research [1]. The perspective analyzes transitions on three levels, the niche, the socio-technical regime and the landscape $[18,19]$. In short, the dynamics between the three levels, i.e., pressures from landscape and from niches, ultimately renders in an unfrozen state of the socio-technical regime, which is a 'window of opportunity' for new innovation to become part of the new re-frozen regime.

In the multi-level perspective, sustainability initiatives are rather commonly seen as 'niche activities' $[18,20,21]$, carried out and developed by start-ups, grassroots and lead 
users $[8,19,22]$. Hence, individuals who chose to engage in entrepreneurial ways because of sustainability beliefs, are acknowledged in the multi-level perspective, but only at the niche level and not as insiders [23].

Another established perspective originating from the science and technology field but commonly used also within sustainability transitions research, is the technological innovation system perspective $[2,6,24]$. This perspective can be characterized as analytical tools for studying system dynamics in the emergence of novel technologies. By analyzing functions of an innovation system, technological innovation system approaches identify system weaknesses and barriers for the development and emergence of technologies. Technological innovation system analyses have been used on a variety of sustainability transitions and has guided policy design to support the development of different technologies, including energy system change $[6,25,26]$.

Work within this perspective highlights the importance of entrepreneurial experimentation e.g., [2,6] and primarily places firms as a key actors in the analysis. However, a few studies have also placed individuals and their transformative capacities as 'system builders' $[27,28]$ or 'entrepreneurs' $[6,25,29,30]$ at the center of the analysis. Some of these individuals' engagement have also been described as driven by sustainability beliefs, e.g., by Hellsmark and Jacobsson [27]. Hence, individuals with entrepreneurial sustainability engagement can be found within technical innovation system analysis. However, this is rare and when so, they have not been depicted as insiders.

The transition management perspective can be characterized as an approach suggesting that transitions can be governed and shaped by policymakers [31,32]. The core of transition management is about organizing interaction between stakeholders, at both niche and regime levels, to enable experimentation and interactive learning among individuals $[33,34]$. This is done through 'transition arenas', which are spaces for change-oriented stakeholder to interact with regime actors for developing ideas and activities as well as search for alternatives [31,35-38]. These alternatives will then challenge the regime in ways that the society can be transformed [31,33].

In transition arenas, 'frontrunners' are brought together to develop shared understandings of complex transitions and break-down long-term visions of sustainability into concrete actions for pathways explorations and developments for societal change [31,38,39]. Frontrunners are visionary individuals with diverse backgrounds, who can 'think outside the box' and engage others to involve in transformative alternatives [35,36]. Transition management embraces the importance of insiders contributing to sustainability initiatives. However, arguably the perspective is more top-down than bottom-up, and little is known about why individuals engage. It is unclear to what extent they are driven by personal sustainability beliefs or other rationales, such as being commissioned or responsive to requests.

\subsection{Entrepreneurship Perspectives}

The mainstream perspective of entrepreneurship can be defined as the discovery, evaluation and exploitation of opportunities to create future goods and services [40]. Entrepreneurship is often associated with 'creative novelty' which is materialized through venture creation, risk taking and increased revenue [41]. It is strongly associated with actions aimed at different market or economic outcomes [42]. There is thus a prevailing relationship between entrepreneurship and the formation of new ventures and market opportunities e.g., [40,41,43-45]. In accordance, the main link between mainstream entrepreneurship and sustainability transitions are through breakthrough disruptive ventures causing Schumpeterian creative destruction, as can be exemplified in the role Tesla electrical cars currently plays within the car industry.

However, the mainstream entrepreneurship perspective hamper exploration of connections between entrepreneurship and the bigger picture of social change [42]. Other drivers, than formation of new ventures and market opportunities, are being missed out. 
Furthermore, entrepreneurial engagement among individuals who stay in an employment, i.e., insiders, is not acknowledged.

Corporate entrepreneurship [46] and intrapreneurship [47] perspectives have pioneered entrepreneurial engagement among individuals belonging to established organizations, i.e., what we call insiders. The literature on corporate entrepreneurship and intrapreneurship has since developed into different concepts, such as internal corporate entrepreneurship, corporate venturing and strategic renewal, to mention a few, see [48], including investigating employees who develop products, services, and/or solutions that links business growth to social value creation e.g., [49,50].

Corporate entrepreneurship and intrapreneurship appreciate insiders choosing to act entrepreneurially at different levels in an organization. Still, the perspective focuses on market opportunities, or on becoming the manager of an important new business within the cooperation [46] (p. 241). The perspective does not connect to the importance of sustainability beliefs as a personal driver for insiders to act.

Social entrepreneurship perspectives focus on how and why individuals chose to engage entrepreneurially for social value creation. Social entrepreneurship emerged in the 1980s around individuals who found opportunities in turning social needs into business. Since then, social entrepreneurship includes the forming any type of organization with a purpose of social value creation [51], and not emphasizing direct financial benefits for the entrepreneurs [51-54].

Social entrepreneurship includes initiatives, such as engaging people outside the labor market, small scale locally and organically food production, and enterprises grounded in developing a local rural context [52]. Personal motivation is a part of the social entrepreneurship literature and it is widely acknowledged that personal beliefs, specifically about nature and the society, are characteristic in motivating social entrepreneurs to create social or environmental benefits over economic values [53,55-58].

Social entrepreneurship acknowledges that individuals' feelings, ethical motives and perceived moral responsibilities can work as catalyzers for social transformation $[53,55,56]$. It is thus a perspective in which individuals engaging in entrepreneurial ways and who are driven by personal sustainability beliefs, are brought to the front. In general, however, insiders are not recognized in this perspective.

As indicated in the overview in Table 1 and now reviewed, established perspectives capture some but not all three aspects asked for. If insiders' bottom-up entrepreneurial engagement into sustainability initiatives is important, then a new perspective is motivated. Such a perspective then challenges the persistent view that insiders act along top-down directives or predetermined role-expectations of the organizations they work for. It also questions a prevalent view within both sustainability transition and entrepreneurship perspectives that entrepreneurship happens through entrepreneurs starting and running new economic ventures where they have private interest.

\subsection{Entrepreneurial Insider Sustainability Engagement Perspective}

The entrepreneurial insider sustainability engagement perspective is a novel way of understanding who starts transition initiatives (insiders), how (individual entrepreneurial choice) and why (personal sustainability beliefs). For such a perspective to help explain transition in energy systems and hopefully also elsewhere, there is a need for a linking of these insiders to institutional change. Recent research into sustainable entrepreneurship [28,59,60] and institutional entrepreneurship [61,62] offers help in bridging between the engagement of individuals, their teamwork and institutional change. Basically, both sustainability and institutional entrepreneurship research, unlike more established entrepreneurship perspectives, highlight norm-changing institutional work. These societal norms can be hard as in legislation and regulations, or more soft and socially embedded $[63,64]$. Hence, in sustainable and institutional entrepreneurship it is not primarily about accomplishing new ventures and new economic value but to achieve institutional change [65]. Nevertheless, case studies into sustainability entrepreneurship mostly 
have independent lead entrepreneurs and their ventures in the center, something our perspective deviates from, while instead shedding light on how insiders engage into entrepreneurial teamwork.

Basically then, insiders self-select into an initiative and affect soft norms by offering and attracting others (including institutional decision-makers) into the initiative. Similar to the description of technology entrepreneurship [66], institutional and sustainability entrepreneurship often emphasize the collectiveness of entrepreneurship [67]. Our perspective embraces that and recognizes central aspects of (emergent) entrepreneurial teams [68] being in play, albeit not in the form of incorporated ventures [69,70], but more as open projects. Recent research into entrepreneurial teams point at overlapping purpose, trust, openness, and complementary interdependent skills to be central features [70,71]. Two case studies of decentralizing energy system initiatives will now help qualify individual-, initiative- and team-levels at work as well as institutional-level effects. The analysis and discussion will then finalize our back ended establishment of a new perspective.

\section{Method}

For this study we examined two contemporary Swedish energy systems initiatives. These initiatives take a 'systemic' approach, rather than testing a specific technology or 'smart' services. Such energy systems initiatives are rare. The selected initiatives represent two of less than a handful of similar initiatives identified in Sweden. Hence, a critical case selection strategy [72] was applied when selecting the cases.

The first initiative, hereafter called the Energy District, is situated at a university Campus' energy grid; the second, hereafter called the Village, is situated in a village in southern Sweden. Specifically, we have investigated the individuals behind these initiatives, who they are and what personal beliefs that steer their engagement for realizing imagined futures of the energy system.

Each case was investigated through a mix of methods [72,73]. Desktop research of websites, policy documents, funding applications and various types of reports and academic literature was done in the initial phases of the case study and to structure a 'hard' timeline (e.g., around project funding, geographical specifications, dates for permits and energy capacity). In semi-structured interviews we then asked questions about the timeline to get a common perceived structure of main events. Alongside questions about the timeline, we also used questions for open-ended narratives [74] around personal beliefs and forms of engagement. Open-ended questions allowed the interviewees' to interpret questions and give extensive answers and make 'think-aloud' contributions about their own, and others', personal beliefs and engagement [75].

Key persons in the two initiatives were identified and interviewed. Starting with the project team of each initiative, a snowballing technique was used to identify all persons who had made key contributions to the initiative. Twenty three semi-structured interviews were conducted between September 2017 and October 2019, ranging in length between one and two hours. Following the explorative purpose of this study, we made a timeline of hard events, for each initiative, and added individuals' voices to build overlapping narratives [76]. These overlapping narratives thus provided space for key entrepreneurial individuals to express their personal beliefs and unique actions, shed lights on team efforts, and structure hard events. Bringing about the personal narratives of entrepreneurial insiders has two purposes: (1) to better understand the who, how and why questions of these individuals in relation to the initiative [77], and (2) to display how the narrative of a sustainability initiative actually affects soft norms around the initiative. This narrative approach is in line with recent developments within entrepreneurship connecting human agency and context, and allowing transition and institutional change to be appreciated [76] as captured in the following citation:

“. . a narrative perspective does not begin with a priori assumptions by researchers on what counts as contexts or how boundaries should be drawn. Instead, a narrative perspective draws attention to attempts by entrepreneurs to contextualize innovation 
through relational, temporal and performative efforts. [ ... ] As different entrepreneurial narratives accumulate, they often reference each other, leading to the emergence of a collective field identity". ([76], p. 1181)

In the subsequent case studies, citations are extensively displayed to allow tracing of individual beliefs and experiences as well as of a more joint narrative [74] resulting in institutional work, at least on the level of changing soft norms. The narratives in this study were then analyzed by a problem-driven abductive methodological approach, iterating empirical findings and theory into the introduced perspective [78].

\section{Case Descriptions}

This section presents two Swedish energy systems initiatives that have evolved around the same time and have both gained a lot of national and international attention. The first case, the Energy District, is an initiative for turning a geographically defined urban energy district (a university campus) in one of Sweden's largest cities into a separate energy district. Different energy carries and storage abilities were used to balance energy usage and production between the buildings in the district. The second case, the Village, is an initiative to develop and understand a small self-sufficient renewable energy society. In Table 2, the key persons engaging into the two cases are introduced.

Table 2. Overview of individuals, personal beliefs and their nature of engagement.

\begin{tabular}{|c|c|c|c|}
\hline Initiative and Organizational Role & Organizational Affiliation & Personal Interest/Reasons for Engaging & Nature of Engagement \\
\hline \multicolumn{4}{|c|}{ The Energy District } \\
\hline Director of Renewable Electricity & $\begin{array}{l}\text { Municipality owned energy } \\
\text { company }\end{array}$ & $\begin{array}{l}\text { Learnings about technical issues in } \\
\text { relation to futures in the energy system }\end{array}$ & $\begin{array}{l}\text { Joined the initiative during a temporary } \\
\text { stand in for the R\&D Strategist. }\end{array}$ \\
\hline $\begin{array}{l}\text { Project Coordinator } \\
\text { (former R\&D Strategist) }\end{array}$ & Science Park & $\begin{array}{l}\text { Technology interests for increased } \\
\text { efficiencies and future roles for } \\
\text { established energy firms }\end{array}$ & $\begin{array}{l}\text { Seizes the opportunity to use the } \\
\text { university campus are for a coordinated } \\
\text { sustainability initiative }\end{array}$ \\
\hline Energy Market Researcher & Research institute & $\begin{array}{l}\text { Future energy system with lower } \\
\text { environmental impact }\end{array}$ & $\begin{array}{l}\text { Self-chosen work for writing the } \\
\text { funding application. Introduces } \\
\text { the local energy market }\end{array}$ \\
\hline Area Manager for Energy & Regional Development Office & Sustainability and energy system values & $\begin{array}{l}\text { Self-chosen work to enable, coordinate and } \\
\text { contributing to an application to an EU call }\end{array}$ \\
\hline Initial Project Leader & Science Park & Fulfilling a professional role & $\begin{array}{l}\text { Professionally engaged with skills and } \\
\text { knowledge about the application process. }\end{array}$ \\
\hline Programmer & Multinational telecom company & Not known & $\begin{array}{l}\text { Professionally engaged with skills and } \\
\text { competences for realizing the local energy } \\
\text { market, using an existing ICT-solution }\end{array}$ \\
\hline Technology Manager & Property Owner at campus & $\begin{array}{l}\text { Innovation interest and energy reduction } \\
\text { for tenants and for the society }\end{array}$ & $\begin{array}{l}\text { Enables sensor implementations and } \\
\text { information sharing }\end{array}$ \\
\hline R\&D Strategist & $\begin{array}{l}\text { Municipality owned } \\
\text { energy company }\end{array}$ & $\begin{array}{c}\text { Future energy distribution systems with } \\
\text { lower environmental impact }\end{array}$ & $\begin{array}{l}\text { Joined the initiative when taking over } \\
\text { it from the former R\&D Strategist }\end{array}$ \\
\hline \multicolumn{4}{|c|}{ The Village } \\
\hline $\begin{array}{l}\text { Director of Strategy and } \\
\text { Business Development }\end{array}$ & Distribution System Operator & $\begin{array}{l}\text { Learnings about technical issues in } \\
\text { relation to futures in the energy system }\end{array}$ & $\begin{array}{l}\text { Marketing the initiative as an } \\
\text { important sustainability initiative }\end{array}$ \\
\hline House Owner & $\begin{array}{l}\text { Grassroot engaged prosumer } \\
\text { and villager }\end{array}$ & $\begin{array}{c}\text { Contribute to environmental } \\
\text { sustainability. Be part of the initiative }\end{array}$ & $\begin{array}{l}\text { Engaged prosumer with potential } \\
\text { return of investment }\end{array}$ \\
\hline Project Leader & Distribution System Operator & Sustainability and energy system values & $\begin{array}{l}\text { Maneuvering the initiative and } \\
\text { selling the benefits with localized } \\
\text { energy system internally }\end{array}$ \\
\hline Region Director & Distribution System Operator & $\begin{array}{l}\text { Localized energy systems with resilience } \\
\text { and lowered environmental impact }\end{array}$ & Self-chosen work to start the initiative \\
\hline Strategist & Distribution System Operator & $\begin{array}{l}\text { Technical challenges and } \\
\text { environmental sustainability }\end{array}$ & Self-chosen work to start the initiative \\
\hline
\end{tabular}

\subsection{The Energy District: Connecting Electricity, Heating and Cooling}

The Energy District is an energy system initiative that has established a district scale demonstrator, uniquely integrating electricity, district heating and cooling. All types of local energy production, usage, surplus and storage functions are utilized to balance between the buildings in the Energy District and across different energy carriers in a way 
that has never been done before. In this initiative, electricity, heating and cooling are also brought into one and the same energy market.

The local market enables energy customers in the Energy District to trade energy using different parameters, such price or $\mathrm{CO}_{2}$-emissions on used energy. It also enables energy costumers to trade flexibility, based on for example the thermal storage capacities of the building.

The Energy District is an initiative located at a university campus, as energy grids on campuses in Sweden are run on the owner's premises, thereby not adhering to the regulations prevalent elsewhere. In the Energy District, the incoming regional electric grid and the district heating system have been connected with local electricity and heat production. Usage and storage are fully automated by an ICT-solution and an artificial intelligent agent, representing each building, analyzing the energy situation and making forecasts for energy use. The agents use weather reports and historical energy data to places or accepts energy bids on a local energy market. A so called 'solver' (also an artificial intelligent agent) clears the bids hourly between the different house specific agents.

Based on an optimization of overall cost, primary energy considerations and/or each building's $\mathrm{CO}_{2}$-emissions, every house-agent uses the house's storage capacities and energy generation to trade on the local energy market. Storage capacities are, for example, batteries and thermal inertia in the building. Each agent thus automatically switches between energy carriers in the house. Taken together, this balances the district's energy systems, which in turn lowers the import of energy from the city's electricity grid and regional district heating network.

"The energy district contributes to reducing energy peaks and at the same time reduces the use of fossil energy, which still dominates the European energy market", says The Director of Renewable Electricity from the municipality owned energy company. He continues: "There are multiple of interesting outputs from this initiative and we can take our learnings to other parts of the energy system. The use of thermal inertia, for example, is very interesting, not least from a district heating perspective. We who own the energy grids must also find new ways to include smaller local energy producing actors. [...] And we need to train for increased electricity price and demand fluctuations in order to provide the future citizens of our city a robust energy system that can handle increased proportions of variable production. [ . . . ] But we also have a parallel discussion internally about the purpose of this initiative and what is it for us. And that discussion has not yet landed".

The Energy District initiative supports the development of energy-sufficient urban areas by demonstrating scalable and replicable solutions for energy efficiency and smart energy management in public infrastructure and housing sector. The initiative has developed a model for moderating the demand for heating and cooling and the deployment of innovative, renewable-based solutions to heat/cool buildings and neighborhoods.

"The [Energy District] initiative confirms our city as a frontrunner in developing the energy solutions of a fossil-free society [ . . . ] Hopefully, the [Energy District] model will speed up energy transitions across Europe" says the Mayor of the City at the time.

"It all started around 2014. At the time I was a RED Strategist at the municipality-owned energy company. We had become a small group of individuals, gathered around a common interest in flexibility issues and smart grids [...] We were working for different employers, such as academia; the property owners at the university campus; a research institute; the city owned Science Park, and the municipality owned energy company [ . . . We all had slightly different interest and drivers in this. The researchers, for example, wanted to test smart grid solutions and investigate flexibility issues in the distribution grid and someone was interested in micro-grids. Personally, I was mostly curious about what a localized energy system would look like and if an established energy company could play a role in such a system" says the Project Coordinator at the Science Park. 
"It was the [former RED Strategist at the municipality-owned energy company, now] Project Coordinator, working at the Science Park, who started to arrange these meetings" says the Energy Market Researcher at the involved research institute. And he continues: "It was a handful of people. Most of us knew each other beforehand. We had informal meetings and just talked a lot about different aspects of potential future energy systems. Although, we didn't have a grand plan, all of us had some common interests-or at least, there was no conflicting interests".

"There was a lot of things going on at the time. I had just changed jobs, moving from being a RED Strategist at the municipality-owned energy company, starting at the Science Park. I was engaged in a project with the director [of an energy area] at the university. We had previously been colleagues at municipality-owned energy company. He was my RED manager back then. Working for the Energy area at the university, he had this idea about using the campus to demonstrate energy solutions [...] There were some scattered projects going on at the campus, focusing on different aspects of smart, intelligent or sustainable energy systems. For example, solar panels were installed at some of the rooftops by one of the property owners at the campus, and there was a research project on energy system flexibility issues, related to an electric bus. But the two of us wanted to do something more coordinated. Something systemic. Something bigger [ . . ] Being at the Science Park, I had the possibilities to engage into this, so I got some friends together to discuss this" says the Project Coordinator.

"It was the Area Manager for Energy, at the Regional Development Office, that found the Urban Innovation Action call. There was a call from the European Commission" says the Initial Project Leader for the Energy District initiative. She continues: "The Urban Innovation Action was launched in 2014, with the objective to test new and unproven solutions to address urban challenges. I was at the time responsible for international relations at the Science Park. I had coordinated a European Union's Horizon 2020 research and innovation program application, focusing on city development and including different aspects of energy efficiency. It had just been rejected, so I had time, and I could bring a lot of experiences from that process into the energy district project".

"It was obvious that the call was relevant for us, because it was just those types of energy system issues that we had been discussing" says the Area Manager for Energy at the Regional Development Office. He continues: "The call was published at the end of December and Christmas holidays delayed the start of the application process. But turning our discussions into an application really got us going. We were short of time because we only had two month or so to the deadline, but we managed [ ... ] I would say that we managed to get the application done in such a short time because we had been talking about this for a while, and we were a constellation of individuals from different actors that already knew and trusted each other [ ... ] Personally I think it is interesting to investigate different types of values. For instance, I have my own solar PV-panel, and sometimes they are good for me, and sometimes they provide more value for the energy system".

"I was thrown into the writing process. The municipality-owned energy company had managed to provide some funding for a consultant to arrange the writing process and assemble all the bits and pieces for the application. But he needed some technical support. There were a few bits and pieces missing. We had the campus as a geographical area and there was this idea about energy exchange within this area-but the question was still how this should be arranged. So, I suggested that it would be cool if we could create a local marketplace-and there it was" says the Energy Market Researcher at the involved research institute.

"It was only two and a half weeks before we had to submit the application when this idea about a marketplace came up. This was the missing piece" says the Project Coordinator at the Science Park, and he continues: "I had a meeting scheduled with an old friend at a Swedish telecom company the day after, so I pitched the idea for him. I didn't know 
what to hope for, but he found it really interesting and he managed to get a permission from his boss during the afternoon and joined right away".

"Working with EU funding proposals was new for me, so I'm glad that the consultant got involved. He did a very good job in squeezing all wishes into one and the same document [ . . . I I provided information about our buildings' energy systems and I think I contributed quite a lot to the technical aspects of connecting different these systems. But just to refit our systems was not enough for the application, so that's why the marketplace came in. [ ... ] Personally, I was most interested in the technical aspects on how to integrate different energy systems in the buildings. I wanted to reduce the total amount of energy usage. That is, what is important for our tenants and for society. The marketplace, as such, is maybe not so relevant for us property owners", says the Technology Manager from the property owner at campus and he continues: "The [Energy District] initiatives has become a success and we communicate it a lot internally and externally. Now we are doing a similar thing at a university campus in the northern part of Sweden. It is not exactly the same, but it is similar when it comes to flexible energy storage and integration of different energy systems."

"The [Energy District] initiative has received a lot of national public attention. But it is still difficult for us to use these things in practice. Flexibility is important, and the [Energy District] initiative has pushed questions about, for example, how we can use district heating. Next generation district heating is probably much more decentralized. But there are regulations, etc. that still need to be changed for us, in order to fully engage in these issues. One great challenge, for example, is the information sharing. There are a lot of different actors who owns different data", says the R\&D Strategist at the municipality-owned energy company. She continues: "Although, people have moved around between different employers through the years, the ones engaging in the [Energy District] initiative still meet to discuss these issues and ideas for future initiatives. We are basically the same group of individuals who engage in these kinds of initiatives-and we have been so for quite a while".

\subsection{The Village: A Local Energy System}

On the shoreline of the Baltic Sea in the very south of Sweden, a village with some 170 households is centered around a majestic church from the 12th century. Here, in this old village one of the largest Distribution System Operators (DSO) and service providers in Europe runs the first 'smart electric grid' in Northern Europe. With $100 \%$ renewable local power generation, the village has become a high-tech autonomous microgrid, able to run in a so called 'islanded mode'. A wind turbine is used as the main power generation. It is supported by a ground-mounted PV power plant of solar cells and a backup bio-diesel power generator to ensure the energy delivery. Two stationary Li-ion and redox-flow technologies batteries are used for instantaneous balancing of the microgrid (i.e., voltage and frequency control). "We think local energy systems are the future. The whole energy system is facing a huge transition and we can see that it is very important to introduce small scale renewable energy production. The local energy system we have created in the village, together with the citizens, is one way for us to contribute to the energy transition" says the Director of Strategy and Business Development at the DSO.

The Village initiative demonstrates a local microgrid with islanding capability and the ability to power a local energy system by using only renewable energy sources. Customers participate in the energy system with their own residential energy resources or appliances, such as heat pumps, PV installations, batteries and hot tap water boilers. These assets can be controlled by the DSO, by a demand-response control system and adjusted according to current needs in the local energy system. "I'm very positive about this. I have just got myself a PV panel on my rooftop and a battery, to be part of this. It is so exiting that this happens in our village" says one engaged House Owner in the village. 
"The customers can voluntarily join the setup through a separate agreement, for which they individually receive a remuneration based on the household's actual contribution and consumption" says the Project Leader for The Village and he continues "It is important for us to have a close dialogue with the customers, or the villagers, and the municipality. So, we employed a communicator early on, for the dialogue with the villagers. The [Village] initiative was received very well. Much better than we expected. I think the possibilities for them to engage has increased their satisfaction".

Since the inauguration in 2016, the initiative has hosted numerous of study-visits on requests from different parts of the DSO, other energy companies, community organizations, local and national press and politicians, and international delegations. "We need many of these types of initiatives in Sweden" said the chairperson of the Parliamentary Committee on Industry and Trade, after a visit in The Village. The project has also received national and international awards and has been acknowledged, for example, by the International Smart Grid Action Network and Global Smart Grid Foundation (ISGAN).

The journey of this initiative started already in 2014, and $1230 \mathrm{~km}$ further up north. "We had, or still have, this customer. It is a couple, who runs a wildlife camp in a in a remote village with less than fifteen residents, in the northern part of Sweden. At the time, they often suffered from 20-30 h power outages, because the electricity grid was substandard in that area. Obviously, this was a problem for them, because they wanted to ensure a positive experience for their customers. I was Operational Manager at the time, so I was assigned to get in contact with them", says the Region Director at the DSO, and he continues: "I called them, and we got along quite well. They actually invited me up, so I brought a trainee, and we flew up to visit them [ . . . ] When we were up there, they suggested that they might as well produce their own electricity. They had windmills at a visible distance, a river passing by, and a lot of land for solar panels. It really made sense, to have it all local. That was when the idea was born. Right there".

Soon after the visit to wildlife camp, a Strategist at the DSO, and long-time close colleague to the Region Director, participated in an internal strategic workshop about the future of the DSO, involving strategists from Germany, Hungary and the Czech Republic:

"The workshop was arranged by our international unit. We were discussing potential consequences of the recently started 'Energiewende' — the phase-out of coal, fossil and nuclear power in Germany. We were asked if we had any initiatives in the pipe-but no one had, really. So, with the wildlife camp in the back of my head, I raised my hand and said that we had a case in Sweden where we could test these things out. [ ... ] These types of projects are both good and bad, because they require some engagement to get them done, but they also come with some money [ ... ] The initiative could therefore be labelled as 'strategic future work' and it made it possible for us to spend some time on it, without being questioned by colleagues in the organization. The very first thing we did was actually to make plans for how we could anchor this internally, because none of us had any idea of what a local energy system would look like [ ... I If I hadn't taken that chance, there would not be a local system in this village. It would probably had become something different, somewhere else".

Together, the Region Director and the Strategist started the initiative in 2014 with the goal to build and test a self-sufficient local energy system, somewhere in Sweden. A trainee was appointed as Project Leader and the three managed to get additional funding from the European Union's Horizon 2020 research and innovation program.

"All of us, who were engaged in the initiative, were very enthusiastic. Even though we didn't have a clue what a local energy system was, we wanted to test if it was possible to produce and use energy locally", says the Strategist. He continues: "There were of course also a lot of people around us, being skeptical about what we were doing. After all, 'the usual way' worked just fine, and it had many advantages [... I I think we all had an idea about changing the energy system and make contributions to a sustainable society. 
Some of us are perhaps more interested in technical challenges, while others more towards sustainability and contributing to the society. But [environmental] sustainability was probably the main driver for all of us."

"As it has turned out, it works great to run the village disconnected from the regional electric grid and still run the village-grid in balance" says the current project manager of the project. And he continues: "The next thing we need to figure out is if there is a business case in this. It has never been a criterion, until now [... I It is like 'Lego', we can use bits and pieces of what we have learnt in other situations [ ... W We have recently started to test different demand-side response technologies for the households to reduce energy peak times and to introduce electric vehicles in the system. I think decentralization in the electricity grid will have a huge effect on future energy systems. But policy is not here yet."

\section{Analysis}

The analysis will investigate the who (insiders?), why (personal beliefs?), how (entrepreneurial action?) and what (transitional effects?) questions asked in this study in relation to the cases. Both energy system initiatives were started and run by insiders. In the Village case there were also engaged grassroots, being enthusiastic prosumers, but not contributing to the systems solutions. When following the trails back to the start of the initiatives, insiders in both cases chose to engage because of personal beliefs about environmental sustainability while also wanting to be system builders' trying out new solutions. Reducing uncertainties about how to make a new decentralized energy system along with sustainability beliefs thus were key drivers behind the individuals engaging as teams around the initiatives. Only in the Village project, and after a while, uncertainties about what any potential business model could be were addressed but not resolved.

In both cases, insiders initiated and developed sustainability initiatives without being expected to do so in their professional roles. Hence, the initiatives were not the result of any top-down decision or mandate. In both cases, insiders utilized their professional networks and different types of resources associated to their organizational role, to achieve the emergence of an energy-system oriented initiative. Hence, they can be seen as having made an independent and entrepreneurial choice to engage, without a mandate, and then started to draw from different types of accessible resources, from their home organizations and beyond. Over many years the key persons independently and during working days raised public funding, used their personal network and encouraged likeminded to join the initiative. At the same time, they managed to uphold trust with their home organizations although their engagement sometimes was met by some skepticism from colleagues.

Both initiatives have had effects far beyond the core teams. Some of the respondents filled a space within their organization's sustainability strategies gaining the label 'strategic future work'. Both initiatives have received local, national and even international attention in media, through rewards, and through public and private decision-makers personally engaging and adding to the narrative, including making study visits and communicating officially. These efforts have not yet changed hard institutional norms, such as energy system regulations. However, they can be seen as more soft institutional work, not only communicating to decision-makers but actually having them involved and personally engaged.

\section{Discussion}

The purpose of this study is to qualify an entrepreneurial insider sustainability engagement perspective that can help us better appreciate how transition, such as in energy systems, can be accomplished. The two cases demonstrate that energy systems initiatives can be started by a handful of insiders moving in and out of their organizational roles. Their narratives are meshed together along with concrete developments of future energy systems [76]. There is institutional work carried out not just by demonstrating new solutions, but also through the decision-makers being attracted to and then adding to the 
narrative. These narratives indicate how soft norms are changing implying institutional change [61].

The individuals engaging into the narrative are driven by different personal beliefs, resources and networks, related to environmental, technological, and/or social issues. With overlap in purpose and a sense of interdependence as regards different skills and resources, they act as an entrepreneurial team [70,71,77], even though there is no lead entrepreneur, no managers and no incorporated venture in play. Most previous research into entrepreneurship - mainstream, social and even more recent sustainability entrepreneurship_has taken lead-entrepreneurs and/or incorporated ventures for granted. The current study instead emphasizes the overlapping purpose and intentions, as well as the expertise and resourcefulness of self-selected individuals, as more constitutive for entrepreneurial teamwork, at least in the current setting. This is in line with recent studies of entrepreneurial teams [70,71,77]. Given that the entrepreneurial insiders in our two cases display no private interest, we can here add the point that teams of insiders more easily might attract attention of decision-makers, and even have them becoming part of the team. An entrepreneurial initiative with a private venture-core would arguably have more difficulties to achieve this institutional effect.

Changes of the energy system will affect the market conditions and challenge incumbent business models for selling and delivering energy. For example, introducing a local energy market, on which different energy carriers are merged, will give energy customers larger abilities to maneuver their use of energy in more dynamic ways. This type of energy system initiatives will thus likely have a negative impact on Swedish distribution system operators' business models. Yet, the current cases show that insiders from incumbents are the only ones being capable enough to develop initiatives that can change institutional conditions. The grassroots, lead users and independent entrepreneurs emphasized in established perspectives are not playing any lead roles. Nor are any top-down decisions, except those behind the calls resulting in the EU grants, available for both initiatives.

To sum up, insiders belonging to a sociotechnical system in need of transition, can be key players initiating such transitions. In the case of regulated energy systems, they might be the only actors making a difference. The way they accomplish transition is through entrepreneurial teamworking in an open non-proprietary project that attracts resources including engaged decision-makers. The narratives about future energy system solutions and what they require are the driving forces in this institutional change, not economic seizing of market opportunities, assumed in both entrepreneurship and sustainability transition perspectives. The narratives into which persons engage affect institutional context and soft embedded norms. When eventually even harder norms change, it will probably be done through top-down decision, whether by elected public officials or executives appointed by boards and their shareholders. The current perspective, just like contemporary research into institutional entrepreneurship [61], focuses on institutional change. It, however, adds insiders, omits lead entrepreneurs and private ventures, and emphasizes the importance of self-selected entrepreneurial teams driven by purpose and complementary skills. Consisting of personally engaged, belief-driven individuals, these teams are open, inclusive and focused on new more sustainable narratives. They are far from the structurally closed descriptions of transitional environments depicted in many established perspectives.

The main limitation of this study is that both cases are selected from the same national setting. Individuals' possibilities of moving in and out of their organizational roles may vary between different national and industry cultures. Future studies from other countries can confirm our results or add additional cultural dimensions. Secondly, although both cases display some major effects, only time will show what impact these two energy system initiatives will have on future energy system and its actors. Additional long-term studies of energy system initiatives are therefore encouraged as well as studies of how entrepreneurial insiders play roles for other transitions. 


\section{Conclusions}

The purpose of this study is to qualify a new insider sustainability engagement perspective to better appreciate how transition can be accomplished, especially around more decentralized energy systems. The study takes stock of two initiatives in Sweden that are focusing on societal and environmental benefits, while at the same time challenging the involved energy companies' current business models. The study contributes to the understanding of how and why transition comes about in energy systems initiatives for decarbonization, lowering energy consumption and enabling self-sufficient energy 'prosumption'.

Basically, the proposed perspective avoids established structural, market-oriented and economic understandings of transition, and, in line with recent sustainability and institutional entrepreneurship research, focuses on institutional change. It does so by applying an inclusive and narrative-based view on how institutional change occur through entrepreneurial teams of insiders driven by overlapping purpose, openness and complementary expertise, and not requiring lead entrepreneurs, economic motives or incorporated ventures.

Implications for policy and research into sustainability transitions are that we need to acknowledge the importance of entrepreneurially engaged insiders. Public project funding plays a vital role in the current initiatives. Corporations having sustainability policies, should also acknowledge the long-term importance of allowing entrepreneurial insider behaviors, as displayed in the current cases. It might not initially result in new growth business, but it will at least keep these companies more aware, agile and perhaps also long-lasting, as inevitable transition happens. Hence, established organizations will not necessarily benefit economically in the short term by trusting its entrepreneurially engaged employees. They will rather build more long-term transition capabilities as well as gain a more attractive reputation in the eyes of many stakeholders. An implication for grassrootinitiatives building so called eco-locations, with decentralized local solutions, is that they should be clear about whether they are testing specific technologies or 'smart' services, or if they are exploring more systemic solutions. In the latter case, they should connect with insider-driven initiatives like the two studied here. These have impact on what in an electricity grid is known as 'before the meter'. Hopefully, such rare system initiatives will soon imply that systemic and institutional interfaces will become more clear, adaptable and easier to transcend.

Author Contributions: Both authors contributed equally. All authors have read and agreed to the published version of the manuscript.

Funding: This research was funded by ENERGIMYNDIGHETEN, grant SAMSPEL.

Institutional Review Board Statement: Not applicable.

Informed Consent Statement: Informed consent was obtained from all subjects involved in the study.

Data Availability Statement: Data sharing not applicable.

Conflicts of Interest: The authors declare no conflict of interest.

\section{References}

1. Köhler, J.; Geels, F.W.; Kern, F.; Markard, J.; Wieczorek, A.; Alkemade, F.; Avelino, F.; Bergek, A.; Boons, F.; Fünfschilling, L.; et al. An agenda for sustainability transitions research: State of the art and future directions. Environ. Innov. Soc. Transit. 2019. [CrossRef]

2. Bergek, A.; Jacobsson, S.; Carlsson, B.; Lindmark, S.; Rickne, A. Analyzing the functional dynamics of technological innovation systems: A scheme of analysis. Res. Policy 2008, 37, 407-429. [CrossRef]

3. Castán Broto, V.; Bulkeley, H. A survey of urban climate change experiments in 100 cities. Glob. Environ. Chang. 2013, 23, 92-102. [CrossRef] [PubMed]

4. Farla, J.; Markard, J.; Raven, R.; Coenen, L. Sustainability transitions in the making: A closer look at actors, strategies and resources. Technol. Forecast. Soc. Chang. 2012, 79, 991-998. [CrossRef]

5. Geels, F. Processes and patterns in transitions and system innovations: Refining the co-evolutionary multi-level perspective. Technol. Forecast. Soc. Chang. 2005, 72, 681-696. [CrossRef] 
6. Hekkert, M.P.; Suurs, R.A.A.; Negro, S.O.; Kuhlmann, S.; Smits, R.E.H.M. Functions of innovation systems: A new approach for analysing technological change. Technol. Forecast. Soc. Chang. 2007, 74, 413-432. [CrossRef]

7. Hellsmark, H.; Frishammar, J.; Söderholm, P.; Ylinenpää, H. The role of pilot and demonstration plants in technology development and innovation policy. Res. Policy 2016, 45, 1743-1761. [CrossRef]

8. Kemp, R.R.; Schot, J.; Hoogma, R. Regime shifts to sustainability through processes of niche formation: The approach of strategic niche management. Technol. Anal. Strateg. Manag. 1998, 10, 175-198. [CrossRef]

9. Seyfang, G.; Smith, A. Grassroots innovations for sustainable development: Towards a new research and policy agenda. Environ. Politics 2007. [CrossRef]

10. Hildén, M.; Jordan, A.; Huitema, D. Special issue on experimentation for climate change solutions editorial: The search for climate change and sustainability solutions-The promise and the pitfalls of experimentation. J. Clean. Prod. 2017, 169, 1-7. [CrossRef]

11. Sengers, F.; Wieczorek, A.J.; Raven, R. Experimenting for sustainability transitions: A systematic literature review. Technol. Forecast. Soc. Chang. 2019, 153-164. [CrossRef]

12. Bergek, A.; Berggren, C.; Magnusson, T.; Hobday, M. Technological discontinuities and the challenge for incumbent firms: Destruction, disruption or creative accumulation? Res. Policy 2013, 42, 1210-1224. [CrossRef]

13. Berggren, C.; Magnusson, T.; Sushandoyo, D. Transition pathways revisited: Established firms as multi-level actors in the heavy vehicle industry. Res. Policy 2015, 44, 1017-1028. [CrossRef]

14. Steen, M.; Weaver, T. Incumbents' diversification and cross-sectorial energy industry dynamics. Res. Policy 2017, 46, 1071-1086. [CrossRef]

15. Turnheim, B.; Sovacool, B.K. Forever stuck in old ways? Pluralising incumbencies in sustainability transitions. Environ. Innov. Soc. Transit. 2020, 35, 180-184. [CrossRef]

16. Smink, M.M.; Hekkert, M.P.; Negro, S.O. Keeping sustainable innovation on a leash? Exploring incumbents' institutional strategies. Bus. Strateg. Environ. 2015, 24, 86-101. [CrossRef]

17. Upham, P.; Bögel, P.; Dütschke, E. Thinking about individual actor-level perspectives in sociotechnical transitions: A comment on the transitions research agenda. Environ. Innov. Soc. Transit. 2019, 34, 341-343. [CrossRef]

18. Geels, F. Technological transitions as evolutionary reconfiguration processes: A multi-level perspective and a case-study. Res. Policy 2002, 31, 1257-1274. [CrossRef]

19. Geels, F.W.; Schot, J. Typology of sociotechnical transition pathways. Res. Policy 2007, 36, 399-417. [CrossRef]

20. Geels, F.; Kemp, R. Dynamics in socio-technical systems: Typology of change processes and contrasting case studies. Technol. Soc. 2007, 29, 441-445. [CrossRef]

21. Rip, A.; Kemp, R. Technological change. In Human Choice and Climate Change; Rayner, S., Malone, E.L., Eds.; Battelle Press: Columbus, OH, USA, 1998; ISBN 0521446309.

22. Avelino, F.; Wittmayer, J.M. Shifting power relations in sustainability transitions: A multi-actor perspective. J. Environ. Policy Plan. 2016, 18, 628-649. [CrossRef]

23. Geels, F. The multi-level perspective on sustainability transitions: Responses to seven criticisms. Environ. Innov. Soc. Transit. 2011, 1, 24-40. [CrossRef]

24. Bergek, A.; Hekkert, M.; Jacobsson, S.; Markard, J.; Sandén, B.; Truffer, B. Technological innovation systems in contexts: Conceptualizing contextual structures and interaction dynamics. Environ. Innov. Soc. Transit. 2015, 16, 51-64. [CrossRef]

25. Hojckova, K.; Ahlborg, H.; Morrison, G.M.; Sandén, B. Entrepreneurial use of context for technological system creation and expansion: The case of blockchain-based peer-to-peer electricity trading. Res. Policy 2020, 49, 104046. [CrossRef]

26. Energimyndigheten. Teknologiska Innovationssystem Inom Energiområdet_En Praktisk Vägledning till Identifiering av Systemsvagheter som Motiverar Särskilda Politiska Åtaganden; Energimyndigheten: Stockholm, Sweden, 2014; ISBN ER 2014:23.

27. Hellsmark, H.; Jacobsson, S. Opportunities for and limits to academics as system builders-The case of realizing the potential of gasified biomass in Austria. Energy Policy 2009, 37, 5597-5611. [CrossRef]

28. Klein Woolthuis, R.J.A. Sustainable entrepreneurship in the Dutch construction industry. Sustainability 2010, 2, 505-523. [CrossRef]

29. Alkemade, F.; Negro, S.; Thompson, N.A.; Hekkert, M.P. Towards a Micro-Level Explanation of Sustainability Transitions: Entrepreneurial Strategies; Innovation Studies Utrecht (ISU) Working Paper Series; Innovation Studies Utrecht: Utrecht, The Netherlands, 2011; pp. 1-32.

30. Bergek, A.; Hekkert, M.; Jacobsson, S. Functions in innovation systems: A framework for analysing energy system dynamics and identifying goals for system-building activities by entrepreneurs and policy makers. In Innovation for a Low Carbon Economy: Economic, Institutional and Management Approaches; Edward Elgar Publishing: Cheltenham, UK, 2008; Volume 79.

31. Loorbach, D. Transition Management for Sustainable Development: A Prescriptive, Complexity-Based Governance Framework. Governance 2010, 23, 161-183. [CrossRef]

32. Rotmans, J.; Kemp, R.; Van Asselt, M. More evolution than revolution: Transition management in public policy. Foresight 2001, 3 , 15-31. [CrossRef]

33. Grin, J.; Rotmans, J.; Schot, J.; Geels, F.; Loorbach, D. Transitions to Sustainable Development: New Directions in the Study of Long Term Transformative Change; Routledge: New York, NY, USA, 2010. [CrossRef]

34. Loorbach, D.; Frantzeskaki, N.; Lijnis Huffenreuter, R. Transition Management: Taking Stock from Governance Experimentation. J. Corp. Citizsh. 2015, 48-66. [CrossRef] 
35. Loorbach, D.; Rotmans, J. The practice of transition management: Examples and lessons from four distinct cases. Futures 2010, 42, 237-246. [CrossRef]

36. Nevens, F.; Frantzeskaki, N.; Gorissen, L.; Loorbach, D. Urban Transition Labs: Co-creating transformative action for sustainable cities. J. Clean. Prod. 2013, 50, 111-122. [CrossRef]

37. Rotmans, J.; Loorbach, D. Complexity and transition management. J. Ind. Ecol. 2009, 13, 184-196. [CrossRef]

38. Wittmayer, J.M.; Loorbach, D. Governing Transitions in Cities: Fostering Alternative Ideas, Practices, and Social Relations Through Transition Management. In Governance of Urban Sustainability Transitions; Springer: Tokyo, Japan, 2016 ; pp. 13-32. ISBN 9784431554264.

39. Wittmayer, J.M.; Avelino, F.; van Steenbergen, F.; Loorbach, D. Actor roles in transition: Insights from sociological perspectives. Environ. Innov. Soc. Transit. 2017, 24, 45-56. [CrossRef]

40. Shane, S.; Venkataraman, S. The Promise of Entrepreneurship as a Field of Research. Acad. Manag. Rev. 2000, 25, 217-226. [CrossRef]

41. Backhaus, J.G.; Schumpeter, J.A. Joseph Alois Schumpeter: Entrepreneurship, Style, and Vision; Springer: Boston, MA, USA, 2003; ISBN 1402074638.

42. Welter, F.; Baker, T.; Audretsch, D.B.; Gartner, W.B. Everyday Entrepreneurship-A Call for Entrepreneurship Research to Embrace Entrepreneurial Diversity. Entrep. Theory Pract. 2017, 41, 311-321. [CrossRef]

43. Baron, R.A. Behavioral and cognitive factors in entrepreneurship: Entrepreneurs as the active element in new venture creation. Strateg. Entrep. J. 2007, 182, 167-182. [CrossRef]

44. Bruyat, C.; Julien, P.A. Defining the field of research in entrepreneurship. J. Bus. Ventur. 2001, 16, 165-180. [CrossRef]

45. Nicholls, A. The Legitimacy of Social Entrepreneurship: Reflexive Isomorphism in a Pre-Paradigmatic Field. Entrep. Theory Pract. 2010, 34, 611-633. [CrossRef]

46. Burgelman, R.A. Corporate Entrepreneurship and Strategic Management: Insights from a Process Study. Manag. Sci. 1983, 29, 1349-1364. [CrossRef]

47. Pinchot, G., III. Intrapreneuring: Why you don't have to leave the corporation to become an entrepreneur. In University of Illinois at Urbana-Champaign's Academy for Entrepreneurial Leadership Historical Research Reference in Entrepreneurship; Harper \& Row: New York, NY, USA, 1985.

48. Sharma, P.; Chrisman, S.J.J. Toward a reconciliation of the definitional issues in the field of corporate entrepreneurship. In Entrepreneurship; Springer: Berlin/Heidelberg, Germany, 2007; pp. 83-103.

49. Belinfanti, T.C. Contemplating the gap-filling role of social intrapreneurship. Or. L. Rev. 2015, 94, 67.

50. Elkington, J. The Social Intrapreneur: A Field Guide for Corporate Change-Makers. 2009. Available online: https://www.allianz. $\mathrm{com} /$ content/dam/onemarketing/azcom/Allianz_com/migration/media/current/en/press/news/studies/downloads/ thesocialintrapreneur_2008.pdf (accessed on 5 August 2020).

51. Mair, J.; Martí, I. Social entrepreneurship research: A source of explanation, prediction, and delight. J. World Bus. 2006. [CrossRef]

52. Gawell, M.; Johannisson, B.; Lundqvist, M. Samhällets Entreprenörer: En Forskarantologi om Samhällsentreprenörskap; KK-stiftelsen: Stockholm, Sweden, 2009.

53. Lindgren, M.; Packendorff, J. Entrepreneurship as Boundary Work: Deviating from and Belonging to Community. In Entrepreneurship as Social Change: A Third Movements in Entreprenerurship Book; Steyaert, C., Hjorth, D., Eds.; Edward Elgar Publishing: Cheltenham, UK, 2006; pp. 210-230.

54. Thompson, J.L. The world of the social entrepreneur. Int. J. public Sect. Manag. 2002, 15, 412-431. [CrossRef]

55. Conger, M. The role of personal values in social entrepreneurship. In Patterns in Social Entrepreneurship Research; Edward Elgar Publishing: Cheltenham, UK, 2012.

56. Leadbeater, C. The Rise of the Social Entrepreneur; Demos: London, UK, 1997; ISBN 1898309531.

57. Patzelt, H.; Shepherd, D.A. Recognizing Opportunities for Sustainable Development. Entrep. Theory Pract. 2011, 35, 631-652. [CrossRef]

58. Murnieks, C.Y.; Klotz, A.C.; Shepherd, D.A. Entrepreneurial motivation: A review of the literature and an agenda for future research. J. Organ. Behav. 2020, 41, 115-143. [CrossRef]

59. Hörisch, J. The Role of Sustainable Entrepreneurship in Sustainability Transitions: A Conceptual Synthesis against the Background of the Multi-Level Perspective. Adm. Sci. 2015, 5, 286-300. [CrossRef]

60. Jayaratne, M.; Sullivan Mort, G.; D’Souza, C. Sustainability entrepreneurship: From consumer concern towards entrepreneurial commitment. Sustainability 2019, 11, 7076. [CrossRef]

61. Woolthuis, R.K.; Hooimeijer, F.; Bossink, B.; Mulder, G.; Brouwer, J. Institutional entrepreneurship in sustainable urban development: Dutch successes as inspiration for transformation. J. Clean. Prod. 2013, 50, 91-100. [CrossRef]

62. Fuenfschilling, L.; Truffer, B. The interplay of institutions, actors and technologies in socio-technical systems-An analysis of transformations in the Australian urban water sector. Technol. Forecast. Soc. Chang. 2016, 103, 298-312. [CrossRef]

63. Scott, W.R. Institutions and Organizations: Ideas, Interests, and Identities; Sage Publications: New York, NY, USA, 2013 ; ISBN 1483321916.

64. Edquist, C. Systems of Innovation: Technologies, Institutions, and Organizations; Psychology Press: London, UK, $1997 ;$ ISBN 1855674521.

65. Lawrence, T.B.; Suddaby, R.; Leca, B. Institutional Work: Actors and Agency in Institutional Studies of Organizations; Cambridge University Press: Cambridge, UK, 2009; ISBN 0521518555.

66. Garud, R.; Karnøe, P. Bricolage vs. breakthrough: Distributed and embedded ageny in technology entrepreneurship. Res. Policy 2003, 32, 277-300. [CrossRef] 
67. Lundqvist, M.A.; Williams Middleton, K.L. Promises of societal entrepreneurship: Sweden and beyond. J. Enterprising Communities 2010, 4, 24-36. [CrossRef]

68. Yusubova, A.; Andries, P.; Clarysse, B. Entrepreneurial team formation and evolution in technology ventures: Looking beyond the top management team. J. Small Bus. Manag. 2019, 11, 1-30. [CrossRef]

69. Schjoedt, L.; Monsen, E.; Pearson, A.; Barnett, T.; Chrisman, J.J. New venture and family business teams: Understanding team formation, composition, behaviors, and performance. Entrep. Theory Pract. 2013, 37, 1-15. [CrossRef]

70. Harper, D.A. Towards a theory of entrepreneurial teams. J. Bus. Ventur. 2008, 23, 613-626. [CrossRef]

71. Nowell, P.; Timmermans, B. Organizational perspective on entrepreneurship. In The Palgrave Handbook of Multidisciplinary Perspectives on Entrepreneurship; Palgrave Macmillan: Cham, Switzerland, 2018; pp. 125-146.

72. Flyvbjerg, B. Making Social Science Matter: Why Social Inquiry Fails and How It can Succeed Again; Cambridge University Press: Cambridge, UK, 2001.

73. Flyvbjerg, B. Five misunderstandings about case-study research. Qual. Inq. 2006, 12, 219-245. [CrossRef]

74. De Fina, A.; Georgakopoulou, A. The Handbook of Narrative Analysis, 1st ed.; John Wiley \& Sons Inc: Malden, MA, USA, 2015.

75. Kvale, S.; Brinkmann, S.; Torhell, S.-E. Den Kvalitativa Forskningsintervjun; Studentlitteratur: Lund, Sweden, 2009; ISBN 9789144055985.

76. Garud, R.; Gehman, J.; Giuliani, A.P. Contextualizing entrepreneurial innovation: A narrative perspective. Res. Policy 2014, 43, 1177-1188. [CrossRef]

77. Lundqvist, M.; Middleton, K.W.; Nowell, P. Entrepreneurial Identity and Role Expectations in Nascent Entrepreneurship. Ind. High. Educ. 2015, 29, 327-344. [CrossRef]

78. Dubois, A.; Gadde, L.E. Systematic combining: An abductive approach to case research. J. Bus. Res. 2002, 55, 553-560. [CrossRef] 